\title{
New Histories of Representing American Suburbs: Race, Place, and Memory
}

\section{Paul Sandul}
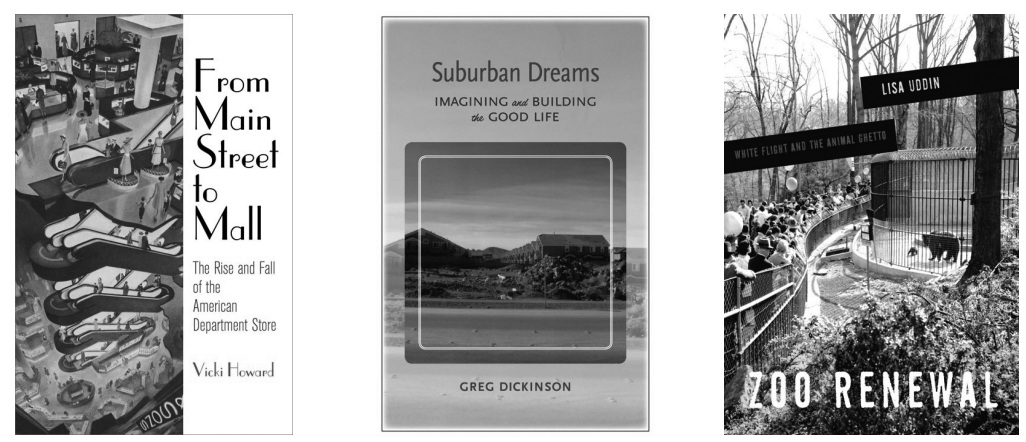

FROM MAIN STREET TO MALL: The Rise and Fall of the American Department Store. By Vicki Howard. Philadelphia: University of Pennsylvania Press. 2015.

SUBURBAN DREAMS: Imagining and Building the Good Life. By Greg Dickinson. Tuscaloosa: The University of Alabama Press. 2015.

ZOO RENEWAL: White Flight and the Animal Ghetto. By Lisa Uddin. Minneapolis: The University of Minnesota Press. 2015.

We have entered a Golden Age of suburban studies. Much has already been made of the so-called "new suburban history" of the early twenty-first century. Earlier scholars of American suburbia had sketched out a vision of suburbia demographically, geographically, and functionally too narrow. ${ }^{1}$ Much of the focus 
was on the migration of the affluent from the city to suburbs, which subsequently excluded economically and socially marginal peoples. This view painted suburbs as predominantly white middle-class enclaves functioning as bedroom communities for residents who depended on cities for jobs, shopping, and leisure. ${ }^{2} \mathrm{New}$ suburban historians challenged these earlier depictions for their omissions: industry; retail outlets; local businesses; multifamily housing; blue-collar workers; minorities; and the poor. They documented industrial suburbs, racial and ethnic suburbs, and more, moving beyond the white middle-class residential archetype. ${ }^{3}$ But, recent works by Greg Dickinson, Vicki Howard, and Lisa Uddin suggest that we may be in thick of a "third wave" of suburban studies.

My first impression of a new wave came when I worked with John Archer and Katherine Solomonson on editing and contributing to Making Suburbia: New Histories of Everyday America (2015). Our driving thrust was to highlight suburban research that looked at suburbanites themselves and how they came to define, understand, and use suburbia as an apparatus for living. We also sought to highlight works on representation, particularly as it helps to influence activity, but also mobilizing, building, and gathering in suburbia. I see much of the same emphasis present in these works by Dickinson, Howard, and Uddin. This is not to say others have not come before us, or that there is an easily definable line demarking one wave of suburban history from another. Progress in the field of suburban studies is often wonderfully, beautifully messy. Some of the elements I see as "third wave" include a more intense focus on the lives of suburbanites themselves and a dissection of representations and cultural landscapes, especially in terms of race.

In Suburban Dreams, Dickinson looks at suburbs as a means for living visions of what he calls the good life. The good life is both a symbolic and material project most often performed in American suburbia. In this way, suburbs structure agency. A connection between the communities people create and the values they have, their sense of self, and their continuous reassembly of both, and vice versa, is central to Dickinson's thesis and is his most powerful contribution. Pulling from spatial theorists like Henri Lefebvre and Michel de Certeau, Dickinson shows how suburbs encompass much more than geographical location or material form. Changing conceptions of the family, home, leisure, separateness and togetherness, security and safety, nature, history, public life, and community life_-various elements of the so-called good life_-all shaped and were shaped by modern American suburbia. Here, the suburban material and symbolic landscapes are instruments of production, or "rhetorical resources," "enabling and structuring-without determining — action" (2). Suburbia therefore constitutes the physical, social, and cultural resources by which suburbanites engage daily life. Moreover, they are simultaneously the effects afforded to suburbanites in the next round of everyday practice and meaning making.

Over three parts and six chapters, Dickinson chronicles how suburbanites indeed act upon suburbs to (re)assemble and live out multiple versions of the good life. In Part I, "Imagining the Good Life," Dickinson devotes two chapters 
to showing how suburbs came to represent the fulfillment of promises about the so-called good life, and how popular culture helped fashion a spatial imagery of suburbia as the best place for living the good life. The post-World War II boom excited economic prosperity and a rapid growth in detached single-family homes. In the midst of this prosperity, American anxieties and fears manifested as well, often involving race and class. In particular, many Americans were concerned about an "urban crisis," and about communist menaces at home and abroad. Suburbia was the remedy and was both the space for the appearance of the good life and the site of its enactment. It promised comfort, safety, and a sense of community (i.e., homogeneity) as a relief to what Dickinson sees as the results of a disruptive modernity. Much like Peter Fritzsche in Stranded in the Present: Modern Time and the Melancholy of History, Dickinson casts modernity as being interpreted as something lost as much as something gained. ${ }^{4}$ This fueled a nostalgia for a mythical past and a sense of "uncanny" (homelessness) for many in search of the so-called good life away from the vilified (and racialized) city. Desiring "locatedness," homogenous suburbs offered a "rhetoric of locality" to provide a sense of belonging in time and space. Of course, Dickinson does not dismiss the role of popular culture in shaping the American conception of the suburbs. Along the lines of Robert Bueka, Catherine Jurca, and Lynn Spigel, Dickinson reviews popular cultural representations of suburbia, mostly through Pleasantville (1998) and Little Children (2006). ${ }^{5}$ In this regard, films serve as constitutive elements of the suburban spatial imagination - as "representational space," which affects the way we can experience space itself. Here, a suburban aesthetic that is decidedly white, domestic, and in tune with nature is propagated and subsequently appropriated by suburbanites striving to enact their vision of the good life. Noting that films like Pleasantville also contain representations of suburbia as maladaptive, Dickinson argues that, thanks to laments about globalization and fears about the loss of tightly controlled suburbs, films like Pleasantville can cast suburbs from an earlier era as that much better, safer, and intimate, and as something for which we should ultimately yearn.

In Part II, "Home and Kitchen: Building Safe and Authentic Space," two chapters elucidate the emergence of, first, the home as a place of safety and security; and, second, how suburban restaurants also evoke images of home and family, thus allowing suburbanites to (perhaps paradoxically) perform such an identity at chain establishments. Looking to the residential architecture of American suburbs, houses emerge as much more than material structures, but also as imagined spaces for living the good life. Suburban homes were thus shaped by the aspirations of their inhabitants (and marketers), specifically through the crafting of an image of home as a safeguard of liberties and the authentic environment to promote better family relations, escape urban vices, and commune with nature. Welcomed here is Dickinson's unspoken challenge to the standard narrative that postwar suburbs are rootless. Critics and scholars like Herbert Gans, Edward Hall, Ada Louise Huxtable, and Jane Jacobs, who never hid their disgust for suburbs, argued that suburbs denied the human need for historical connectedness. Suburbs, 
they claimed, weakened individual and social identities by pulling people out of history. ${ }^{6}$ My own work, as well as work by Heather Bailey and Martin Dines, shows this view to be too simplistic. ${ }^{7}$ Suburbanites do find meaning in their past and work to memorialize, preserve, and even consecrate it. Dickinson goes further however. He reveals that if suburbs produced rootlessness or a sense of placelessness among suburbanites, then it was that feeling of uncanny that drove them to the postwar suburbs in the first place. Through nostalgic architecture and romanticized nature, suburbanites have brought the past into the present. From this basis, in perhaps the most fun chapter of the book (chapter 4) - and no shame should come from saying so-Dickinson digests the meaning of Italian-themed restaurants in suburbia, such as Olive Garden, as sites that, first, replicate a home environment for family-dining, and, second, do so based on romanticized notions of white ethnicity that are now synonymous with family intimacy and small-town, rural ideals. Placing it squarely within the context of globalization, Italian food itself is nostalgic on the one hand, and, on the other, such restaurants are sites of legitimation that connect and reinforce the lifestyle choices of suburbanites.

In Part III, "Consuming Suburbs: Building Sacred and Civic Space," Dickinson highlights both the role of megachurches in sacralizing and legitimating suburban visions of the good life and emergence of new shopping destinations called "lifestyle centers" that attempt to recreate the civic feel and purpose of a nostalgic vision of downtown. Much like suburban restaurants, megachurches legitimate suburban norms. Here, megachurches and their attendees appropriate, rather than shun, popular culture in music, consumption, media, and branding. Suburban megachurches' architecture, for example, reflects nearby shopping plazas and office buildings, comfortable and familiar places to many suburbanites. Marked by a low-barriers model of casualness, megachurches are meant to, once again, feel familiar and legitimate suburban norms - be it from selling coffee, rocking out with the praise band to Jesus, or buying CDs at the church book store. Finally, with the demise of department stores (highlighted in more depth by Vicki Howard below), there has been a growth of "lifestyle centers" marked by carefully designed streets and sidewalks scaled down to replicate nostalgic visions of a small-town/downtown America that was more intimate and more civic. In contrast to department stores and malls, with front-of-the-store parking, sidewalks, fountains, gazebos, parks, and even museums, the lifestyle centers of the twenty-first century are more than just consumer spaces, but also noncommercial gathering spaces for suburbanites.

In From Main Street to Mall Vicki Howard traces the rise and fall of the American department store in depth. More than a history of just the more famous and glamorous stores however, Howard focuses on the industry as a whole and convincingly argues that the rise and fall of department stores was not inevitable. Rather, their rise was an accomplishment. As was their fall. Numerous players are present and influential throughout department store history, most notably the entrepreneurs and the government. Howard moves beyond the classical capitalist 
market-driven explanation of the rise and fall of department stores to uncover the fascinating role, responsibility, and, ultimately, culpability of government. On the one hand, government helped facilitate the rise of the industry through favorable legislation and regulations, while, on the other hand, government, epitomized by the neoliberal state from the Reagan era onward, facilitated the decline of department stores by way of deregulatory practices that gave advantages to so-called big box stores like Wal-Mart and the lifestyle centers described by Dickinson.

Over eight chapters, plus an introduction and conclusion, Howard follows the origins of department stores through the late nineteenth century and twentieth century and their growth through World War I, the Great Depression, postwar sprawl, and, ultimately, their decline with neoliberal deregulation at the end of the twentieth century. Like Susan Porter Benson and Alison Isenberg, Howard reveals how department stores and the downtowns they helped create did not rise organically, but were shaped by local actors who facilitated the rise of a consumer society first in major urban areas, then in the nation as a whole. ${ }^{8}$ Borrowing from advancements made in transportation and communications, first utilized by wholesalers like A. T. Stewart, department stores ushered in new developments in advertising, especially aimed at women, by hiring professional ad designers by the 1890s. The idea was not to just advertise the product, but rather to build reputation and target the middle and working classes in addition to the upper class. Numerous innovations allowed for the rise of department stores, from a free entrance policy to lavish promotional spectacles and architecture that signaled luxuriousness. Of course, growth did not come unchallenged, as many small-town merchants and critics decried the rise of mass-retailers as monopolies whose lower prices gave them an unfair advantage. The kicker is, that while government seemed to give lip service to disfavoring big business, the close ties forged between department stores and government facilitated their growth nonetheless. In fact, opposition to department stores had the effect of promoting solidarity and identity since the industry then felt besieged. Representing themselves as victims, department stores formed powerful trade associations and, by joining with Word War I propaganda efforts, cemented a relationship with the government. Indeed, thanks to the leadership of the National Retail Dry Goods Association during the war, not only did the industry modernize and rationalize, but they also helped push through favorable legislation defeating minimum pricing laws, successfully shaping a narrative of high prices as hurtful to consumers and as weakening "business efficiency."

By the end of the 1920s, local department stores were flourishing. Indeed, by the $1920 \mathrm{~s}$, there were about four-thousand department stores in operation. Not surprisingly, as much more than just economic institutions, department stores were imbued with cultural significance. Department stores began to gain favorable representations in popular culture (e.g., Our Blushing Brides, 1930) when they once had been derided by negative portrayals like those in Edwin S. Porter's film The Kleptomaniac (1905). Department stores had, in fact, "come to stand for the might of American capitalism and the democracy of goods" 
(53). The time was ripe for such change. The rise of finance capitalism allowed for new avenues of growth, as did new building materials that allowed lesser stores to shine up and compete. Above all was advertising, which grew from $\$ 30$ million in 1880 to $\$ 600$ million by 1910 . By 1928 , US businesses had spent $\$ 2$ billion on advertising while ushering in more promotional tools and gimmicks like gift registries and their own store branded merchandise. Still, despite the national advertising craze, department stores stayed local and acted as sources of community pride. Even as chain stores emerged, like Montgomery Ward, Sears, and, above all, JC Penny, they also appealed to localism, selling themselves as indeed "local." The chain store movement's so-called revolution in distribution and centralized buying gave them a competitive advantage over department stores whose rising gross margins and operating costs spurred mergers, such as the formation of the huge holding company Federated Department Stores in 1929. Increased competition from chains, cars, and other rival offerings in the consumer's republic led to an increase in the number of services and amenities department stores offered, especially those targeted to women.

Howard shows how the Great Depression forced department stores to change. In the wake of the economic crisis, the industry suffered as sales dropped $41 \%$ and store after store closed their doors. Decentralization - a process begun in the 1920 s thanks to the automobile and chain stores locating at the margins of town because of parking and land costs - essentially hurt local businesses. Many stores looked to improve and expand and/or modernize nonetheless. They increased their advertising and publicity, but this also drove up their costs. Yet, the industry's most meaningful actions came by way of collaboration with the government. Cooperating with President Franklin D. Roosevelt's National Industrial Recovery Act and its agency the National Recovery Administration (NRA), the industry proudly signaled that "We Do Our Part," accepting hesitantly, for example, minimum wage regulation in hopes it would help raise purchasing power and stimulate the economy. Yet, when talk turned to pricing regulation the industry turned sour and fueled a powerful backslash that utilized and popularized the language of "big regulatory government" being in opposition to the "consumer's interest." The NRA was later declared unconstitutional, but the experience helped set several precedents, such as industry-government cooperation and business lobbying. This cooperation actually manifested again quickly during World War II as department stores were enlisted into the "arsenal of democracy" as "soldiers of defense." With a leadership role in the War Production Board, the department store industry highlighted the role of business in the war effort while also moving to cut costs, such as elaborate customer services. Of course, as with the NRA, the industry did not welcome wartime price controls though larger firms benefited from government contracts. Ultimately, older laissez-faire attitudes prevailed and hostility to government returned.

America's move to the suburbs following World War II is well documented. Department stores, of course, were no exception, precipitating the fall of the downtown central business district. As suburbs and auto sales grew, parking 
became more and more of an issue for downtown department stores. In popular culture, downtown stores still ruled. In reality, they were losing. Department stores began to follow the chains, opening branch stores in suburban shopping centers to stay afloat and compete. By 1966, over half of all department store sales were made in branch stores. Moreover, as they moved and catered to a homogenized suburban white middle class, the stores became more standardized. Government also helped. It pumped money into urban renewal programs that further shaped the geography of not just housing, but also retail and race organization alike. The latter is tragically known well, but the former also played a key role in the decentralization of American housing, shopping, and leisure, while further cementing segregated landscapes by race and class - altering life chances. The irony, as Howard keenly sees it, is that downtown department store leaders saw urban renewal as their potential salvation when, in fact, it was their undoing as the resulting federal spending often aided decentralization. Moreover, while calling for federal aid (even if it hurt in the end), the industry again lent its powerful voice to decrying the regulatory state when it came to integration and opening up more opportunities for African Americans and other oppressed groups.

As sprawl altered the landscape of America, so too did a "discount revolution" that struck a chord in suburbia and then subsequently spread from there. "Entrepreneurial discounters" expanded into national chains and established themselves on the outside of downtown areas and central business districts. Discounters catered to a growing consumer culture, "enabling larger proportions of the population to partake the 'good life,' even as promise of low prices came at the expense of high wages and a producer ethic" (167). The final nail, it seems, came with the passage of the 1975 Consumer Goods Pricing Act that restricted pricing to a manufacturer's suggested list price, which was essentially no restriction since suggested list prices could not be legally enforced. Into this environment charged K-Mart, Target, and, of course, Wal-Mart. Cutting costs to the bone, they could undersell competitors. To try and to survive this new onslaught of competition, department stores actually increased their costs by offering high service and luxury as a means to compete via socioeconomic class appeals. Ultimately, the discounters hurt department stores, especially downtown, and, further, began consolidating their grip on consumer retailing. The consequences have been legion, though Howard hits upon a powerful one when noting one effect to have been "a loss of retail diversity and a blander consumer experience as shoppers had fewer choices" (195). Another consequence had been the loss of a "memory space," which Dickinson's work highlighted. That is, with the loss of local, downtown (or main street stores), locals lost local/regional nameplates and, hence, sources of parochial pride and identity. This has created an odd nostalgia for lost "palaces of consumption."

Indeed, the consequences of the neoliberal state are one of Howard's most welcomed additions to the budding suburban history of the twenty-first century. Certainly works by Dolores Hayden, Jon C. Teaford, James Jacobs, David M. P. Freund, Robert O. Self, Matthew Lassiter, and many more have noted the power- 
ful role government played in intervening to create a segregated, decentralized, and sprawling society. ${ }^{9}$ Howard does too. Howard, however, fast forwards to show how interventionist and influential the neoliberal non-regulatory state has been in shaping our world today that the so-called free enterprise system and weak regulatory oversight has eroded so much freedom of choice, opportunity, and hope. Not only do we have suburban sprawl and a more bland and standardized consumer shopping experience, but fewer choices too. Conglomeration has won and weakened or destroyed innumerable family-run stores, small-town main streets, downtown central business districts, and local nameplates. Moreover, with retailers cutting prices and their costs, part-time labor has increased, wages have lowered, and benefits stripped (all of which disproportionately effects the female labor force). The result is a weakening of purchasing power, stagnant real wages and income, outsourcing of jobs, a growing need for welfare and assistance, and a growing gap between the rich and the poor. Indeed, the largest group of the poor today is the so-called suburban poor (16.5 million), who are, further, moving into suburban districts that lack assistance programs and welfare institutions. ${ }^{10}$ The emergence of the super elite, of course, threatens democratic institutions as they further reflect the efforts of powerful lobbying groups to sway politicians. This in turn threatens to weaken civic participation as well.

Urban renewal and interventionist culprits are at play once again in Zoo Renewal by Lisa Uddin. She looks at the revitalization of animal displays in the 1960s and 1970s, placing this phenomenon squarely within the discourses surrounding the so-called urban crisis and government funded urban renewal. In this context, zoo renewal, which emphasized the need to heal and regenerate animal displays, did not only correlate with the urban crisis, but was also a powerful element in the urban renewal programs of the era that sought to supposedly build a better environment for all and thereby rejuvenate the American dream. As with urban renewal itself, this was all "a raced/sexed/classed instrument for the elaboration and legitimation of imperialism, nationalism, and other normative constructions of being and belonging" (8). Here, zoo renewal fit within-and constituted a part of - an anti-urban discourse that sought to reinforce normativity of race, class, gender, and sexuality. On the one hand, animals were linked to non-white people of the city who fell below the ideal, "imbuing non-human creatures with objectionable traits, forms of behavior, and living conditions associated with racial and ethnic minorities" (11). Like the nation's "blighted" cities, zoos were an American shame that needed remediation. On the other hand, zoo renewal, again interweaving with urban renewal, represented the fictions of white people who sought to not only shape the appearance and meaning of cities (and the people within) more in tune with their own desires and uses, but also reassemble the meaning of specific animals living in zoos so as to mark them (i.e., both the zoo and the special animals) as privileged and thereby emblematic of, and safe for, white people.

In five chapters, Uddin looks to undress the history of "feeling bad" at zoos and what was subsequently done to rectify it. First, she utilizes the idea of the 
"Naked Cage," a term borrowed from zoo curator Dale Osborn who sounded the proverbial alarm as it concerned America's zoos. Again correlating it with an urban crisis and view of cities, Uddin reveals how both zoos and cities were cast as dilapidated spaces in need of noble and liberal, if not guilt-induced, intervention. Second, she deploys case studies of the National Zoo in Washington, D.C. and the San Diego Zoo and Wild Animal Park to expose how zoo renewal fit within the regional experiences of redeveloping the city on the one hand (Washington, D.C.), and reproducing, while normalizing, the suburban experience on the other (San Diego). Finally, in both cases, so-called "white" animals (i.e., the white tiger in Washington and the white rhinoceros in San Diego) were hued with privileged meanings to stand in for-and redeem - white racial hopes and anxieties.

While not formally divided into parts, it nevertheless might help readers to mentally organize the book into three logical parts. The first part, chapter one, establishes zoos and cities as sites of shame. The second part, chapters two and three, concentrates on Washington, D.C., first by contextualizing the correlation between urban and zoo renewal, and then by looking at the white tiger, Mohini, as symbolic of white racial fantasies. The third and final part focuses on San Diego by, once again, first contextualizing zoo renewal, but this time in terms of suburban sprawl and development. Lastly, the final chapter on white rhinoceroses serves much the same purpose as the chapter on the white tiger in Washington, D.C., but, of course, brings out the particulars of meanings for this animal within a unique, place-based context.

In Washington, D.C., zoo renewal must be placed within the context of both the shame of the naked cage and the urban crisis, especially as many feared the dilapidated zoo was a blow to the city and represented the loss of a national show piece. First, Uddin highlights a "rhetoric of a zoological slum" whereby the National Zoo emerged as a space for material and moral deprivation. Here, broken cages and unmanageable animals (who even killed a young zoo goer breaching inadequate barriers) were correlated with the anti-urban and racist discourse of urban blight at the heart of urban renewal rationalization as well. As Washington, D.C. looked to cure its "blight," so too did the National Zoo, first with a new bird "sanctuary" deemed appropriate for postwar middle class whites to gaze upon "tame" animals within acceptable surroundings, and, then, a new lion house that was more rustic and picturesque, reflective of anti-urban rural romanticism. In San Diego, developers targeted suburbanites who were uneasy about the huge growth and diversification of the region and, hence, their spatial future and longing for an idyllic, more rural past. As both the city and suburbs grew, San Diegans sought sanctuary from urban life through a vision of open space. "They composed suburban animal dwellings for the viewing pleasure of San Diegan home owners," concludes Uddin, "who were disturbed by contemporary discourses of urban decline, and suburbanized accordingly" (159). That is, the zoo itself suburbanized and, as Dickinson might argue, worked to both recreate the familiar and yearned-for while simultaneously legitimating such lifestyle choices and (racialized) versions of the good life. The zoo thus created 
"tract housing for animals" (167) that looked like the popular ranch houses of California sprawl. Moreover, animal spaces were about intermingling different specific species in controlled spaces, no doubt, but also about sunshine and outdoor living, helping shape the Wild Animal suburb of the San Diego Zoo.

When it came to representing whiteness, the National and San Diego zoos turned to the white tiger and white rhinoceros respectively. In D.C., the white female tiger Mohini offered a counter to the older discourse of "wild" animality as synonymous with non-white "others" as inferior and uncivilized. Mohini was bought, exhibited, and (eugenically) bred for not only her white phenotype, but also the white racial identities of her new adorning fans. She gave the zoo, and thus the city and white middle class, a positive reflection of themselves. Mohini represented a whiteness integral to the zoo renewal efforts and aided the antiurban renewal program of Washington, D.C. In San Diego, white rhinoceroses were brought in, bred, and made the zoo's flagship. They were represented as endangered, much as their surrounding suburbanites viewed themselves, and placed within a large naturalized African-safari scene legitimating, again, white racial preferences and desires. Of course, both animals were, well, animals. A longer history of fetishizing animals and anthropomorphism, for better or worse, contributed to their representational power, as well as limitations. For Mohini, she represented exotic orientalism and royalty on the one hand, but white maternal superiority and reproductive fitness on the other. Yet, she could roar like a tiger and her offspring did not always turn out white or live long. For the white rhinoceroses, they were cast as gentle and in stark contrast with the supposedly more aggressive, truculent, and unpredictable black rhinoceroses. Yet, the white rhinoceros was not so white, in fact. Black and white rhinos are in reality a similar gray color. Whiteness, in other words, was a tough construct to maintain. Thus, it was best sustained and viewed in a manufactured natural setting reflective of American suburbia.

When considering these works altogether, it is hard to miss the focus on race, especially whiteness. These works shine a light on the continued (re)assembly of race in America, marking it not only as socio-cultural, but political, economic, and, well, (sadly) human. While a focus on race is not anything new in suburban history/studies (such as Eric Avila's breakdown of a "spatiality of whiteness"), the attention given to representations and their relationship to racial construction and meaning-making in these works, be it in relation to animals, consumption, or places, is illuminating and intense nonetheless - as is underscoring the power of representations generally. ${ }^{11}$ That is, representations do not merely do the good work of representing, they are also tentative manifestations of the social, cultural, political, and "other" processes through which they are produced and valued, as well as the possible basis for which to question and analyze subsequent human activity and practice in suburbia. Of course landscapes are as symbolic as they are built, lived in and manipulated as they are concrete. But they are built. And the attention given to the (re)creation of physical space as a result of practice as well as a means for practice signals a distinct spatial turn within suburban 
studies as well. If I were to find any major fault in these works, together or individually, I would be hard pressed. Perhaps their only sin in casting suburbia as the old guard may have: primarily white, middle class, and residential. But the histories gained from their analyses place these works on the must-read list of any serious student of American suburbia. I look forward to assigning them in my classes soon.

\section{Notes}

1. For discussions on the "new suburban history," see Kevin Kruse and Thomas Sugrue, eds., The New Suburban History (Chicago, IL: University of Chicago Press, 2006), 1-10; Matthew Lassiter, "The New Suburban History II: Political Culture and Metropolitan Space," Journal of Planning History 4, no. 1 (February 2005), 75-88; Margaret Pugh O' Mara, "Suburbia Reconsidered: Race, Politics, and Prosperity in the Twentieth Century," Journal of Social History 39, no. 1 (Fall 2005), 229-44; Becky Nicolaides and Andrew Wiese, eds., The Suburb Reader (New York, NY: Routledge, 2006), 5-11; Amanda Seligman, "The New Suburban History," Journal of Planning History 3, no. 4 (November 2004), 312-333; and Mary Corbin Sies, "North American Urban History: The Everyday Politics and Spatial Logics of Metropolitan Life," Urban History Review/Revue d'histoire 32, no. 1 (Fall 2003), 28-42. Recent examples of new suburban history works has grown large, perhaps too large to sufficiently list, thus, here are some names of the many scholars who have produced some seminal works: Dolores Hayden, Matthew Lassiter, Robert Harris, Robert Lewis, Lisa McGirr, Sylvia Murray, Becky Nicolaides, Robert Self, Christopher Sellers, and Andrew Wiese.

2. Kenneth Jackson's Crabgrass Frontier (1985), together with works by John Archer, Henry Binford, Michael Ebner, Robert Fishman, Ann Durkin Keating, Margaret Marsh, and John Stilgoe, usually receive demarcation as the founding literature of either the "orthodox" suburban history or, idiosyncratically, the old "new suburban history." John Archer, "Country and City in the American Romantic Suburb," Journal of the Society of Architectural Historians 42, no. 2 (May 1983), 139-56; Henry Binford, The First Suburbs: Residential Communities on the Boston Periphery, 1815-1860 (Chicago, IL: University of Chicago Press, 1985); Michael Ebner, Creating Chicago's North Shore: A Suburban History (Chicago, IL: University of Chicago Press, 1988); Robert Fishman, Bourgeois Utopias: The Rise and Fall of Suburbia (New York, NY: Basic Books, 1987); Kenneth Jackson, Crabgrass Frontier: The Suburbanization of the United States (New York, NY: Oxford University Press, 1985); Ann Durkin Keating, Building Chicago: Suburban Developers and the Creation of a Divided Metropolis (Columbus: Ohio State University Press, 1988); Margaret Marsh, Suburban Lives (New Brunswick, NJ: Rutgers University Press, 1990); and John Stilgoe, Borderland: Origins of the American Suburb, $1820-1939$ (New Haven, CT: Yale University Press, 1989). To be clear, with the exception of Sam Bass Warner, Jr.'s 1962 Streetcar Suburbs: The Process of Growth in Boston, 1870-1900 (New York: Athenaeum, 1962, reprint 1976), Jon Teaford's 1979 City and Suburb: The Political Fragmentation of Metropolitan America, 1850-1970 (Baltimore, MD: Johns Hopkins University Press, 1979), and, to a lesser extent, Lewis Mumford's 1961 The City in History: Its Origins, Its Transformations, and Its Prospects (New York, NY: Harcourt, Brace \& World, 1961), the old "new suburban historians" delivered a more intense examination of suburbs than previously given by historians. Three groupings thus emerge, regardless of their label: (group A) Mumford and Warner-Teaford is in reality not mentioned very often (though footnoted a lot), (group B) Archer, Binford, Ebner, Fishman, Keating, Jackson, Marsh, and Stilgoe, and (group C) Harris, Lassiter, Lewis, Nicolaides, McGirr, Rome, Self, and Wiese.

3. A large body of works have focused on African Americans, minorities, industrial deconcentration, and working suburbs. These works not only challenge the stereotype suburbs are for the middle class, but also demonstrate a trend in examining non-white suburbs that the new suburban historians claim an earlier cohort reified. See, Margaret Crawford, Building the Workingman's Paradise: The Design of American Company Towns (New York, NY: Verso, 1995); Timothy Fong, The First Suburban Chinatown: The Remaking of Monterey Park, California (Philadelphia, PA: Temple University Press, 1994); Richard Harris, Unplanned Suburbs: Toronto 's American Tragedy, 1900 to 1950 (Baltimore, MD: Johns Hopkins University Press, 1996); Richard Harris and Robert Lewis, "The Geography of North American Cities and Suburbs, 1900-1950: A New Synthesis," Journal of Urban History 27, no. 3 (March 2001), 262-93; Dolores Hayden, Building Suburbia: Green Fields and Urban Growth, 1820-2000 (New York, NY: Vintage Books, 2003), 97-127; Greg Hise, Magnetic Los Angeles: Planning the Twentieth-Century Metropolis (Baltimore: Johns Hopkins University Press, 1997); Wei Li, "Building Ethnoburbia: The Emergence and Manifestation of the Chinese Ethnoburb in Los Angeles' San Gabriel Valley," Journal of Asian American Studies 2, no. 1 (February 1999), 1-29; Robert Lewis, ed., Manufacturing Suburbs: Building Work and Home on the Metropolitan Fringe (Philadelphia, PA: Temple University Press, 2004); Becky Nicolaides, My 


\section{Paul Sandul}

Blue Heaven: Life and Politics in the Working-Class Suburbs of Los Angeles, 1920-1965 (Chicago, IL: University of Chicago Press, 2002); Mary Pattillo-McCoy, Black Pickett Fences: Privilege and Peril among the Black Middle Class (Chicago, IL: University of Chicago Press, 1999); Thomas Sugrue, The Origins of the Urban Crisis: Race and Inequality in Postwar Detroit (Princeton, NJ: Princeton University Press, 1996); Alexander von Hoffman, Local Attachments: The Making of an American Urban Neighborhood, 1850-1920 (Baltimore, MD: Johns Hopkins University Press, 1994); Andrew Wiese, Places of Their Own: African American Suburbanization in the Twentieth Century (Chicago, IL: University of Chicago Press, 2004); and William Wilson, Hamilton Park: A Planned Black Community in Dallas (Baltimore, MD: Johns Hopkins University Press, 1998).

4. Peter Fritzsche, Stranded in the Present: Modern Time and the Melancholy of History (Cambridge, MA: Harvard University Press, 2004)

5. Robert Beuka, SuburbiaNation: Reading Landscape in Twentieth-Century American Fiction and Film (New York, NY: Palgrave, 2004); Catherine Jurca, White Diaspora: The Suburbs and the Twentieth-Century American Novel (Princeton, NJ: Princeton University Press, 2001); and Lynn Spigel, Make Room for TV: Television and the Family Ideal in Postwar America (Chicago, IL: University of Chicago Press, 1992).

6. See Mike Wallace, Mickey Mouse History and Other Essays on American Memory (Philadelphia, PA: Temple University Press, 1996), 20-21; and Pierce F. Lewis, "The Future of the Past: Our Clouded Vision of Historical Preservation," Pioneer America 7 (July 1975), 1-20.

7. Paul J. P. Sandul, California Dreaming: Boosterism, Memory, and Rural Suburbs in the Golden State (Morgantown: West Virginia University Press, 2004); Heather Bailey, "Does this Place Really Matter? The Preservation Debate in Denver's Postwar Suburbs," in John Archer, Paul J. P. Sandul, and Katherine Solomonson, eds., Making Suburbia: New Histories of Everyday America (Minneapolis: University of Minnesota Press, 2015), 109-23; and Martin Dines, "Metaburbia: The Evolving Suburb in Contemporary Fiction," in Archer et al, Making Suburbia, 81-90.

8. Susan P. Benson, Counter Cultures: Saleswomen, Managers, and Customers in American Department Stores, 1890-1940 (Urbana: University of Illinois Press, 1986); and Alison Isenberg, Downtown America: A History of the Place and the People Who Made It (Chicago, IL: University of Chicago Press, 2004).

9. Hayden, Building Suburbia; Teaford, City and Suburb; James A. Jacobs, Detached America: Building Houses in Postwar Suburbia (Charlottesville: University of Virginia Press, 2015), David Freund, Colored Property: State Policy and White Racial Politics in Suburban America (Chicago, IL: University of Chicago Press, 2007), Robert Self, American Babylon: Race and the Struggle for Postwar Oakland (Princeton, NJ: Princeton University Press, 2003); and Matthew Lassiter, The Silent Majority: Suburban Politics in the Sunbelt South (Princeton, NJ: Princeton University Press, 2006).

10. Josh Sanburn, "The Rise of Suburban Poverty in America," Time, July 31, 2014, accessed DATE, http://time.com/3060122/poverty-america-suburbs-brookings; and Hope Yen, "'Bright flight' changes then face of cities, suburbs," NBCNews.com, May 9, 2010, accessed DATE, http://www. nbcnews.com/id/37041770/ns/us_news-census_2010/t/bright-flight-changes-face-cities-suburbs/.

11. Eric Avila, Popular Culture in the Age of White Flight: Fear and Fantasy in Suburban Los Angeles (Berkeley: University of California Press, 2006). 